\title{
The Effect of Interval Training on Running Speed of 40-Meter on Elementary Students' Running Performance
}

\author{
Suparlan, Syamsul Arifin, Maruful Kahri \\ Department of Sport and Health Education \\ Lambung Mangkurat University \\ Banjarmasin, Indonesia \\ suparlan@rockrtmail.com
}

\begin{abstract}
The students of SDN Tebing Siring 3 have a low running performance, so the researcher concludes that the students of SDN Tebing Siring 3 do not good running speed. This research aims to determine the effect of interval training on the running speed of $\mathbf{4 0}$ meters of the students of SDN Tebing Siring 3 in Tanah Laut District. The research used the pre-experimental design. Data were collected through the pretest, the treatments for 16 meetings, and the final test. The population in this research were all students of SDN Tebing Siring 3, Tanah Laut District, class IV, and V, amounting to 42 persons, while the sample in this research were 20 students chosen by using a purposive sampling technique. The results showed that running speed based on pretest data was an average $=7.1195$ seconds with a standard deviation $=0.32830$. Based on data from the posttest, a running speed of 40 meters is an average $=6.8730$ with a standard deviation $=0.33106$. The results of the analysis showed $t$-count $=9,487>t$-table (19: $0.025)=2,093$, with Sig. (2-tailed) = 0,000; Apparently Sig. (2tailed) $<0.05$ thus the t-test is significant. The conclusion is that there is an influence of interval training on the 40-meter running speed of the students of SDN (state elementary school) Tebing Siring 3 in Tanah Laut District.
\end{abstract}

\section{Keywords: training, intervals, speed, running}

\section{INTRODUCTION}

The National Education System which states that education is a conscious and planned effort to create an atmosphere of learning and teaching process so that students actively develop their potential to have spiritual strength, self-control, personality, intelligence, noble character, and the skills needed by themselves, the community, nation and state [1]. The competency-based curriculum is a curriculum that emphasizes the development of the ability to perform specific performance tasks, and the results can be beneficial for students in the form of a set of competencies in the form of skills, accuracy, and success with full responsibility. Athletics is one of the materials given to students in elementary schools, namely walking, running, and jumping. Running is one of the numbers competed in the athletics, for example, in the National Student Sports Olympiad (O2SN), usually held at the district/city, provincial and national levels.

Based on the results of observation, when participating in the O2SN selection at local level athletics, the students are always inferior to the students of the other schools, even though the training has been carried out in extracurricular activities at school. In participating in athletics competitions, especially short distance runs at the regional level; students have not shown maximum performance. Therefore, severe treatment is needed through training. The numbers for running short distances are 100 meters, 200 meters, and 400 meters. Running speed is the maximum speed carried by the runner along the distance that must be traveled. Speed (speed) is the ability of a person to make continuous movements in the same form in the shortest time [2].

To achieve an achievement requires a training process with a relatively long duration of time, namely training in a programmed and continuous manner. Coaches and athletes must understand the factors that affect a person's running ability to produce maximum speed movements. According to reference [3] that "the ability to run fast is influenced by 2 (two), namely (1) physiological factors and (2) performance, among others: (1) energy system and (2) neuromuscular system."

In the National Student Sports Olympiad (O2SN) elementary school athletic kids competed for several numbers, namely (1) kanga's escape (sprint and goal) $40 \mathrm{~m}$, (2) frog jump, (3) turbo throwing, and (4) formula 1 (run, obstacles, slalom) $80 \mathrm{~m}$. Forty meters running speed can be achieved if an athlete has an element of maximum speed. How do athletes can maintain maximum speed immediately after starting to finish the finish line? Maximum speed can be achieved with some form of interval training method training.

From the description above, the researchers chose the training method that was allegedly able to increase speed, namely the interval training method. This training method aims to increase running speed, namely the method of interval training, to increase maximum speed [4]. Starting from the description above, the writer feels interested in research and further research the effect of interval training on increasing the speed of the students of SDN (state elementary school) Tebing Siring 3 in Tanah Laut District.

\section{METHOD}

The method used in this research is the pre-experiment design [5]. It is said to be a pre-experiment design because the design of this research is not a real experiment yet, or there are still external variables that influence the formation of the dependent variable. So the experimental results of the dependent variable are not solely influenced by the independent variables. This can happen because there are no control variables; the sample is not chosen randomly. The design in this research used the One-Group Pretest-Posttest Design, which means that before the treatment was given, there was a pre-test, and after the treatment was given a posttest. Thus the results of the treatment can be known more 
accurately because it can be compared with the conditions before being given treatment

\section{RESUlTS AND DISCUSSION}

The results of the data obtained in the research field: pretest of the running speed of 40 meters performed by the students of State Elementary School (SDN) Tebing Siring 3 in Tanah Laut District obtained an average of 7.11195 seconds; with the highest score of 6.64 seconds and the lowest score of 8.00 seconds; whereas in the posttest of the running speed of 40 meters performed by the students of State Elementary School (SDN) Tebing Siring 3 in Tanah Laut District obtained an average of 6.8730 seconds; with the highest score of 6.42 seconds and the lowest score of 7.85 seconds. The above data clearly showed that there was an increase in the average before treatment and after treatment. This showed that the interval training could increase the running speed of the students of State Elementary School (SDN) Tebing Siring 3 in Tanah Laut District.

Based on the results of statistical analysis with the t-test as presented in the table above as follows; 1) the results of the t-test analysis of the pretest variable with the posttest running speed of 40 meters performed by the students of State Elementary School (SDN) Tebing Siring 3 in Tanah Laut District, obtained t-count $=9,487>$ t-table $(19 ; 0.025)=2,093$, or with Sig. $(2$-tailed $)=0,000$; it turns out that Sig. (2-tailed) $=0,000<0.05$ thus the $t$-count is significant. So it can be concluded that there is an effect of interval training on the running speed the students of State Elementary School (SDN) Tebing Siring 3 in Tanah Laut District.

In this research, interval training is provided according to the correct interval training procedure. This training is carried out within four weeks for 16 meetings with a frequency of 4 times a week. Before the exercise, the students were given a running speed test of 40-m. The research samples were the 10-12 years old elementary school students of the fourth and fifth grades. Then after being given the interval training treatment for four weeks, a final test of the running speed of the 40-m was conducted. It turned out that after analyzing the results of the initial test and the final test showed an increase in running speed of 40$\mathrm{m}$ performed by the students of State Elementary School (SDN) Tebing Siring 3 in Tanah Laut District and the influence of interval training on the running speed 40-m of the students of State Elementary School (SDN) Tebing Siring 3 in Tanah Laut District so that this exercise can be applied in schools for example, in extracurricular activities in schools to improve student running speed or student achievement.

This interval training used a maximum intensity, namely, 90-100\% of the maximum running speed of the 40$\mathrm{m}$ that was conducted at the time of the initial test. This is in line with the reference [6] "Training zone intensities for sprint training: 1) zone 1: intensity is very low, its maximum percentage is $<50 ; 2$ ) zone 2 : intensity is low, its maximum percentage is $50-70$; 3) zone 3 : medium intensity, maximum percentage is $70-80$; 4) zone 4 : intensity heavy, maximum percentage is $80-90 ; 5)$ zone 5 : maximum intensity, maximum percentage is $90-100$; 6) zone 6 : supramaximal intensity, maximum percentage is > 100 ". Meanwhile According to reference [4] that "excitatory volume (training) in the exercise of speed is always maximum even supramaximal in its intensity, then the training volume tends to be low and moderate, for that, the recommended training volume is 10 to 20 times of the distance from the actual distance to be contested one. Where the training volume is divided into several reps in 3-4 series each set, with short mileage or short working time ". The application of the set is 3-4 sets according to the opinion of reference [4] above, on the frequency and time of recovery and time interval, the researcher applied the recovery time of 1: 9 , paired the time interval to apply 1:12. According to reference [4] that "frequency of speed training ranges between 2-4 times per week, depending on the stage of the training periodization that was taking place ". According reference [4] that "the ratio between work time and rest time, for recovery time (tr) 1: 9-10, while for the time interval (ti) 1: 12-13, meaning, if the working time is 3 seconds, then the recovery ranges from 30 seconds and an interval time of 36 seconds ".

In this research, there are weaknesses. One of these is that there is a possibility of when the samples are the elementary school students; they still do not understand about the exercise. Therefore, it is necessary to make a particular approach so that they continue to enthusiasm to practice in accordance with the planned program. Sometimes the weather is rainy so that the exercise is done after the rain which allows the children to move less than the maximum. However, the researcher has tried his best to make this research run well and smoothly in accordance with the planned program.

\section{CONCLUSION}

The conclusion of this research is based on the results of the analysis of research data, research hypotheses, the results of the research discussed in the previous chapter, that there is a significant influence of the training interval on the 40-meter running speed of the students of SDN (state elementary school) Tebing Siring 3 in Tanah Laut District.

\section{ACKNOWLEDGMENT}

We want to be grateful to the Dean of Teacher Training and Education Faculty, Lambung Mangkurat University, who has supported us in the form of funding. Therefore we could join this International Conference.

\section{REFERENCES}

[1] Undang-undang No.20 Tahun 2003. Sistem Pendidikan Nasional (SISDIKNAS). Bandung: Citra Umbara.

[2] Mastur Riadi, 2010. Raih Kebugaran Jasmani Melalui Latihan Beban (Weight Training). Mataram: Alfabeta.

[3] Lubis, Johansyah, 2013. Panduan Praktis Penyusunan Program Latihan. Jakarta: PT Raja Grafindo Persada

[4] Sukadiyanto, 2011. Pengantar Teori dan Metodologi Melatih Fisik. Bandung: Lubuk Agung.

[5] Sugiyono, 2014. Metode Penelitian Kombinasi (Mixed Methods). Bandung: Alfabeta.

[6] Bompa, Tudor O, 2009. Periodization Theory and Methodology of Training (Fifth Edition). United States of America: Human Kinestics. 